\title{
An Improvement Capability to Critical Thinking of Students through the Dota Model in Social Studies Learning
}

\author{
NurulRatnawati ${ }^{1}$, AgungWiradimadja ${ }^{2}$, Sukamto $^{3}$ \\ \{nurul.ratnawati.fis@um.ac.id ${ }^{1}$, agung.wiradimadja.fis@um.ac.id ${ }^{2}$, sukamto.fis@um.ac.id ${ }^{3}$ \} \\ ${ }^{1,2,3}$ Social Studies Program, Faculty of Social Science, Universitas Negeri Malang, Indonesia
}

\begin{abstract}
This research aims to: (1) described the Dota model in social studies learning, (2) described the Dota model can improve the ability to critical thinking of students, (3) described the difference between improving capability to critical thinking of students who use the Dota model on the experiment class with the control class. This research used a quantitative approach with the quasi-experiment. Data collection using two techniques, which are (1) tests and (2) survey. The result showed that the ability to critical thinking of students increased significantly afterward applied to the Dota model. Based on the results of the pretest on experiment class, the results of 2 students just completed. While posttest $86 \%$ of students who completed.
\end{abstract}

Keywords: capability to critical thinking, social studies learning, Dota learning model.

\section{Introduction}

The $21^{\text {st }}$ Century fundamentally changes human activity globally. These changes take place quickly, unexpectedly, uncertainly, and increasingly complex. The change is very dramatic and occurs at an exponential speed. This happens because of the impetus for the development of increasingly modern information technology. The world of education also experienced these changes. One of the changes that are evident in the world of education today is the birth of a generation of strawberries that has a uniqueness or uniqueness compared to the previous generation [1].

Many other terms that can be used to refer to strawberry generation include millennial generation, generation Y, generation Z. Not many people understand that the children who attend school and higher education today are the new generations who are unique. They are Generation Z, born in mid-1990-2010. Besides being called the Z generation of Z genes, they are also often called digital natives, screeners, and gamers.

Generation $\mathrm{Z}$ has various advantages. The advantages include: (1) teach savvy; (2) Actively engaged in social media; (3) learn by exploring; (4) committed to their learning and development; and (5) life long learning [2]. Z generation is very familiar with technology, the internet, and social media. Rothman states that they cannot live in a world without the internet, cellphones or iPods [3]. They are men who answer the questions based on the information from the internet such as Google and YouTube. However, they lack critical thinking skills in understanding theoretical studies and evaluating the use of resources. Their brain is influenced by the use of the internet, including in terms of entertainment such as 
online games. Difficult issues this generation from the internet try to be exploited by researchers to implement learning online game models. On the other hand, 21 st-century life also requires generation $\mathrm{Z}$ to master a variety of skills. The US-based Partnership for $21 \mathrm{st}$ Century Skills (P21), identified the skills needed in the 21st century, namely "The 4Cs" (communication, collaboration, critical thinking, and creativity). It is hoped that education can prepare students to master these various skills to become successful individuals in life [4].

Therefore, improving the quality of learning is a challenge for educators to produce a communicative, collaborative, critical and creative generation. Based on a variety of research results have been carried out to prepare students to have 21st-century skills. Among other studies conducted by Finita efforts to improve 21st century skills through project-based learning models [5]; Umami, Risa, and Budi Jatmiko about the application of inquiry learning models with the Science, Environment, Technology and Society (SETS) approach to improve students' critical thinking skills [6]; Tantri explained in the results of his research that problem-based learning and project-based learning are learning models that are able to practice 21st century students' skills [7]. In contrast to some of the results of previous studies that further explain that constructivist-based learning models namely inquiry, PBL, and PjBL as models to improve 21 st-century skills. This research is interested in applying game-based learning models to improve one of the 21 st-century skills namely critical thinking skills.

The reason researchers used a game-based learning model is that this research is a followup study, in which the initial stage the researcher has succeeded in developing a game-based learning model with the name of the Dota learning model, so that in this study is an effort to apply the Dota learning model to improve skills critical thinking [8]. Referring to some research on game-based learning Kickmeier-Rust \& Albert the results of the study show that games can provide an environment for learning problem-solving skills, communication skills, social skills, and other skills that are necessary for life and success or what is often referred to as 21st Century skills [9]. Based on the above, the purpose of this article is (1) describe the application of the model Dota in social studies learning, (2) describe the application of the model Dota can m Enhancing critical thinking skills of students, (3) describe the difference between the increase in critical thinking skills of students using the model Dota in the experimental class with the control class.

\section{Method}

The study was conducted at a junior high school in Malang, using a quantitative approach with a quasi-experimental method. The study was designed by applying two pretest and posttest tests to the control class and the experimental class. Both the control and experiment classes were selected based on the same problem in both classes, namely the low level of student critical thinking. The class that we made as a control class numbered 30 students consisting of 13 males and 17 females, while the experimental class consisted of 31 students consisting of 12 males and 19 females.

Our aim of this experiment is to examine and explain the results of the learning implementation of the Dota model to students' critical thinking skills in learning social studies. This model was adapted from an online game called Dota which was played by two opposing teams. The two teams compete with each other and fight trying to defeat their opponents. The rules in this online game are adopted in the learning model. We give different treatments to the two classes. In the experimental class, the Dota model learning implementation was carried out, while the control class carried out the direct model learning model implementation. When 
implementing Dota learning models, there were only 30 students present, so the students we sampled were only those who were present when implementing the Dota learning model.

\section{Result and discussion}

The implementation of the Dota model includes several steps, namely: 1) providing game tools, 2) group divisions, 3) organizing students for discussion, 4) helping independent and group investigations, 5) group incorporation, 6) giving instructions on Dota game rules, 7 ) each team asked questions and answers alternately, 8) analyzing and evaluating the results [10]. The results of the summary table 1 show that the Dota learning model is implemented very well. The details of the observations of the two teachers can be seen in table 1 .

Table 1. Recapitulation of Dota learning model implementation

\begin{tabular}{cccc}
\hline Class & Observer & $\begin{array}{c}\text { Value } \\
\text { obtained }\end{array}$ & Criteria \\
\hline \multirow{2}{*}{ Experiment } & 1 & 89 & Very Well \\
& 2 & 87 & Very Well \\
\hline
\end{tabular}

Here are the results of research in the form of increasing students' critical thinking skills after using the Dota model. Based on the hypothesis testing of two independent samples (not correlated) on the data of students' critical thinking skills, the value of $t$ arithmetic is 2.84 and the $t$ table is 2.00 , meaning that $t$ arithmetic is greater than $t$ table. This shows that there are differences in students' critical thinking skills that are taught with the Dota model compared to learning using the direct learning model. Analysis of each aspect can be seen in table 1.

Tabel 2. Comparison of pre-test and post-test results in the Control and Experiment Classes

\begin{tabular}{ccccc}
\hline Component & Control & $\begin{array}{c}\text { Pre Test } \\
\text { Experiment }\end{array}$ & Control & $\begin{array}{c}\text { Post Test } \\
\text { Experiment }\end{array}$ \\
\hline Total Student & 30 & 30 & 30 & 30 \\
Average & 47 & 53 & 68 & 72 \\
$\begin{array}{c}\text { \% Mastery } \\
\text { learning }\end{array}$ & 0 & $22 \%$ & $80 \%$ & $86 \%$ \\
$\begin{array}{c}\text { The number of } \\
\text { students who do } \\
\text { not completely } \\
\text { study }\end{array}$ & 30 & 25 & & \\
$\begin{array}{c}\text { The value } \\
\text { mastery learning }\end{array}$ & $\geq 72$ & $\geq 72$ & 6 & 4 \\
\hline
\end{tabular}

Based on the exposure in table 2, it shows that there is an influence of the Dota model on increasing students' critical thinking skills. The experimental class showed higher results compared to the use of direct learning models. This is because many learning activities on the 
Dota model can support students' critical thinking skills. Some of these activities include: first, the Dota model is a game based model. Through games, students are invited to be actively involved in learning. Papastergiou states that through game-based learning students become more active and more motivated, and give a deeper impression than is done using conventional methods [11]. Students are more motivated and compete with each other in learning groups with game models. The activeness of students in learning is what can improve critical thinking skills.

Second, students are guided by the teacher discussing in groups to understand the material and then making questions in the realm of high-level thinking collaboratively. High-level thinking is a process of deep and extensive thinking skills that involves critical and creative information processing in dealing with and solving complex problems and involves analyzing, evaluating and creating skills [12]. Examples of high-level thinking questions according to S. Krulick \& Rudnick are: what's if...?, What's wrong...?, What would you do...?, And what're another way... not just asking "what". These four question words can be the key to starting students asking high-level thinking[13]. Third, students are confronted with some of the opposing team's critical questions, in this context, students learn about critical thinking, problem-solving skills, strategic ability, and competitive. This potential is important as an initial provision to prepare students to be able to face the challenges of life in the future with all its problems. Activities such as those described above, are believed to be able to improve students' critical thinking skills.

\section{Conclusion}

Based on the results of research and discussion it can be concluded that the Dota model can improve students' critical thinking skills. The Dota Model can be used as a solution to improve students' critical thinking skills among other learning models.

\section{References}

[1] Kasali R. Strawberry generation. Anak-Anak Kita Berhak Keluar Dari Perangkap yang bisa membuat mereka rapuh. Bandung: Mizan Pustaka; 2018.

[2] Seta AK. Menyiapkan generasi inovator Indonesia. [Malang]: Universitas Negeri Malang; 2017.

[3] Rothman D. A Tsunami of Learners called Generation Z. 2014; Maryland Police and Correctional Training.

[4] Zubaidah S. Mengenal 4c: learning and innovation skills untuk menghadapi era revolusi industri 4.0. 2019;1-18.

[5] Dewi F. Proyek buku digital: upaya peningkatan keterampilan abad 21 calon guru sekolah dasar melalui model pembelajaran berbasis proyek. Metodik Didaktik: Jurnal Pendidikan Ke-SD-an. 2015;9(2).

[6] Umami R, Jatmiko B. Penerapan model pembelajaran inkuiri dengan pendekatan sets (science, environment, technology and society) pada pokok bahasan fluida statis untuk meningkatkan keterampilan berpikir kritis siswa kelas XI SMA Negeri 1 Gedangan. :9.

[7] Mayasari T, Kadarohman A, Rusdiana D, Kaniawati I. Apakah model pembelajaran problem based learning dan project-based learning mampu melatihkan Keterampilan Abad 21? Jurnal Pendidik FISdan Keilmuan JPFK. 20 Maret 2016;2(1):48. 
[8] Ratnawati N, Wahyuningtyas N. Lesson study in strengthening the role model learning dota in the course practice field study (KPL). International Conference on Lesson Study Universitas Muhammadiyah Malang; 2017; Universitas Muhammadiyah Malang.

[9] Kickmeier-Rust MD, Albert D. A Domain model for smart $21^{\text {st }}$-century skills training in game-based virtual worlds. 2012 IEEE 12th International Conference on Advanced Learning Technologies [Internet]. Rome, Italy: IEEE; 2012. pp. 680-1. http://ieeexplore.ieee.org/document/6268215/

[10] Ratnawati N, et., al. Dota Gamification in Learning. International Conference on Social Studies and Environmental Issue; 2019; Universitas Negeri Malang.

[11] Papastergiou M. Digital Game-Based Learning in high school Computer Science education: Impact on educational effectiveness and student motivation. Comput Educ. 2009;52(1):1-12.

[12] Hidayati AU. Melatih Keterampilan Berpikir Tingkat Tinggi Dalam Pembelajaran Matematika pada Siswa Sekolah Dasar. 2017;4:14.

[13] Krulik S, Rudnick JA. The new sourcebook for teaching reasoning and problemsolving in elementary school. Boston: Allyn and Bacon; 1995. 365 p. 